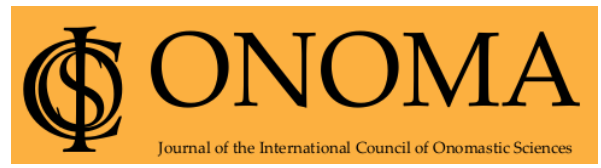

Onoma 56

Journal of the International Council of Onomastic Sciences

ISSN: 0078-463X; e-ISSN: 1783-1644

Journal homepage: https://onomajournal.org/

\title{
First names of Zagreb Jews from the beginning of the 19th century until World War Two
}

\section{Igor Kusin*}

Faculty of Humanities and Social Sciences

University of Zagreb, Croatia

To cite this article: Kusin, Igor. 2021. First names of Zagreb Jews from the beginning of the 19th century until World War Two. Onoma 56, 187-210. DOI:

10.34158/ONOMA.56/2021/10

To link to this article: https://doi.org/10.34158/ONOMA.56/2021/10

(C) Onoma and the author.

\section{Article history}

Received on 26 October 2020.

Final form accepted on 12 December 2021.

Published online on 13 December 2021.

First names of Zagreb Jews from the beginning of the 19th century until World War Two

Abstract: The continuous presence of Jews in Zagreb can be traced back to the end of the 18th century.

Following the anthroponymy of Zagreb Jews from the first census to the beginning of World War Two (in which the community was almost destroyed), this paper analyses the first names of Zagreb Jews based on three sources: Gavro Schwarz's book History of the Zagreb Jewish community from its foundation to the 1850s (Zagreb, 1939), Jewish birth registers from 1849 until 1898, and data collected from the Israelite (Jewish) section of the Old Cemetery at Mirogoj. 
The data analysed include: "civic" or vernacular first names of Zagreb Jews, their frequency, origin and languages from which they were directly borrowed; "Judaic" first names, their frequency and their etymological structure; relationships and links between individual "civic" and individual "Judaic" first names. All these inquiries are pursued separately for masculine first names and for feminine first names.

Keywords: Zagreb Jews, first names, civic first names, Judaic first names.

\section{Les prénoms des juifs de Zagreb du début du $\mathrm{XIX}^{\mathrm{e}}$ siècle à la Deuxième guerre mondiale}

Résumé : Il est possible de remonter jusqu'à la fin du XVIII ${ }^{\mathrm{e}}$ siècle pour tracer la présence continue des Juifs à Zagreb.

Afin de suivre l'anthroponomie des Juifs de Zagreb depuis le premier recensement jusqu'au début de la Deuxième guerre mondiale, cet article analyse les prénoms des Juifs de Zagreb selon trois sources : le livre de Gavro Schwarz Histoire de la communauté juive de Zagreb depuis sa fondation au milieu du XIX siècle (Zagreb, 1939), le registre juif des naissances 1849-1898, ainsi que les données collectées par la section israélite (juive) de l'ancien cimetière à Mirogoj.

Les données étudiées comprennent : les prénoms « civiques » ou vernaculaires des Juifs de Zagreb, leur fréquence, l'origine et les langues auxquelles ils ont été directement empruntés ; les prénoms «judaïques », leur fréquence et leur structure étymologique; les relations et les liens entre les prénoms individuels « civiques » et ceux «judaïques». Toutes ces recherches ont été menées séparément pour les prénoms masculins et ceux féminins.

Mots-clés : Juifs de Zagreb, prénoms, prénoms civiques, prénoms judaïques.

\section{Jüdische Vornamen vom Beginn des 19. Jahrhunderts bis zum Zweiten Weltkrieg}

Zusammenfassung: Die ständige Anwesenheit der Juden in Zagreb lässt sich lückenlos bis zum Ende des 18. Jahrhunderts zurückverfolgen.

Die Namenforschung der jüdischen Vornamen in Zagreb (von den allerersten Aufzeichnungen bis zum Beginn des 2. Weltkrieges) basiert auf drei Quellen. Diese wurden laut der Angaben der jüdischen Gemeinde fast vollkommen zerstört.

Die erste Quelle ist das Buch von Gavro Schwarz „Die Geschichte der jüdischen Gemeinde in Zagreb“. Die zweite Quelle ist der Geburtsregister der jüd. Gemeinde vom 1849 bis 1898. Die dritte Quelle sind sämtliche Urkunden der israelitischen Abteilung der jüd. Gemeinde des Alten Friedhofs in Mirogoj. Die analysierten Daten umfassen sowohl die bürgerlichen als auch die „heimischen“ Vornamen der Zagreber Juden. Darin sind ihre Häufigkeit, Herkunft sowie die Sprache, aus der sie unmittelbar entlehnt wurden, zu finden; jüdische Vornamen, und ihre etymologische Struktur, auch die Ähnlichkeit aufgrund der Beziehungen zwischen den einzelnen „,bürgerlichen“ und individuellen jüdischen Vornamen. Die weiblichen Vornamen sind von den männlichen getrennt zu durchforschen.

Schlüsselbegriffe: Zagreber Juden, Vornamen, bürgerliche Vornamen, jüdische Vornamen. 


\section{First names of Zagreb Jews from the beginning of the 19th century until World War Two}

IGOR KUSIN

\section{A short historical introduction}

The oldest document (a court file) mentioning a Jew in Zagreb (Elias Judaeus) dates to 1373 (Kronologija židovstva u Hrvatskoj). In the 15th century, several Jewish families lived in Zagreb, as can be seen from the documents issued by the historian Ivan Krstitelj Tkalčić (1840-1905) in his opus Povjestni spomenici slob. kralj. grada Zagreba priestolnice Kraljevine dalmatinsko-hrvatsko-slavonske (1889.-1905.) [Historical monuments of the Free Royal City of Zagreb, the capital of the Kingdom of Dalmatia-CroatiaSlavonia (1889-1905)]. He wrote about the Zagreb "domus Judeorum" from the 15 th century ${ }^{2}$ and mentioned names of several Jews from the judicial acts of that time. However, up to this day no information was found documenting a Jewish Community in Zagreb at that time (Schwarz 1939: 7). The small Jewish population in Gradec came to an end by the mid-15th century, when all Jews were expelled from the city (Goldstein 2004: 14).

Zagreb became a united city according to the Imperial Patent on 7 September, 1850 , by incorporating the royal free city on Mount Gradec, the bishopric city of Kaptol, Nova Ves, Vlaška Ves, as well as the suburbs and villages belonging to those towns. Consequently, all Jews living in Zagreb before that date fell under two jurisdictions, either under the municipal one in Gradec or under the bishopric on Kaptol. Therefore, Jews who wanted to settle in the city had to apply for a special permission either to the city magistrate or to the bishop, depending on the part of the city in which they intended to reside (Schwarz 1939: 9).

The first permanent Jewish settlers in Zagreb arrived at the end of the 18th century. In 1782, the first "tolerated" Jew, Jakov Stiegler, from Trebitsch (Třebíč) in western Moravia, moved to Zagreb with such a special permission. He was issued a residence permit the following year (Schwarz 1939: 9; Goldstein 2004: 14). In 1789, Elias Herschl and Jakov Weiss, both from Rechnitz in Burgenland (Hungarian Rohonc, Burgenland Croatian Rohunac), Josephus

1 This paper is based on the presentation of the same name held on 3 June 2019, at the Fourteenth International Conference on Jewish Names at the Bar-Ilan University in Ramat-Gan, Israel.

2 Kronologija židovstva u Hrvatskoj dates a burglary into it in the year 1444. 
Fisher from Miskolczino in northern Hungary (present-day Miskolc) and Jacob (Jacobus) Stern from Lübenau in Pomerania (today's Lubiki in Poland) followed (Schwarz 1939: 9, 13; Goldstein 2004: 14). These first Jewish settlers were mostly engaged in retail trade, opening small shops or peddling. At the beginning of the 19th century only nine Jewish families lived in Zagreb (Goldstein 2004: 14-15). ${ }^{3}$

Despite this division between the two municipalities, the Jews in Zagreb, united in a single Jewish community in 1806 , probably due to their small number - only some 20 families - with seventy-five members (Schwarz 1939: 9). Three years later, Zagreb welcomed its first Rabbi, Aron Palotta (1776 or 1777-1843) (Goldstein 2004: 14).

As the available data show (Schwarz 1939: non-paginated insert between pp. 8 and 9, 13, 45-93), most Jews who immigrated to Zagreb came from various parts of the Austro-Hungarian Empire or from German lands and they were Germanophone and Hungarophone Ashkenazim (Brandl 2015: 56; Goldstein 2004: 61), ${ }^{4}$ with a small minority of Italian Jews from Gorizia and its surroundings who kept their Italian first names (Achille, Adolfo, Camillo, Eduardo, Egidio, Girolamo, Giudita, Guido, Grazietta, Margherita, Paola, Roberto, Stefano) and were most often endogamous. Until World War One the Zagreb Jewish Community was a marginal one in a predominantly German- and Hungarian-speaking state.

After World War One, state borders changed and the possible ties between members of the Zagreb Jewish Community and the places they or their ancestors came from, if existing at all, were disrupted by new frontiers between newlyestablished states. Zagreb became part of the short-lived State of Slovenes, Croats and Serbs that was quickly absorbed by the Kingdom of Serbs, Croats and Slovenes which would change its name into Kingdom of Yugoslavia in 1929. The Zagreb Jewish Community thus became the most important Ashkenazi one in the new, predominantly Slavic-speaking state and had to establish new ties with other Jewish communities, which were mostly Sephardic. This new situation has probably prompted some changes in naming attitudes among the Jews of Zagreb.

Another event in Zagreb itself could have also influenced the choice of names. The Croatian National Revival in the middle of the 19th century aimed towards the creation of a Croatian nation in the modern sense of that word. Its leaders, who bore German and Hungarian names for the most part, changed their first and/or family names in order to sound more Slavic. Thus, the son of German immigrants Ludwig Gay (1809-1872) became Ljudevit Gaj, Jakob

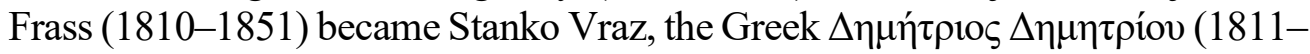

3 The list of Jewish families under municipal jurisdiction published by Gavro Schwarz in the table between pp. 8 and 9 (Schwarz 1939) lists nine families, but the list of Jews under the bishopric from 1812 from the same source (Schwarz 1939: 13), listing eight more families, should also be taken into account.

4 See also Table 1: Jezična asimilacija hrvatskih Židova, 1880-1931 [Language assimilation of Croatian Jews, 1880-1931] (Goldstein 2004: 18) and Table 2: Jezična asimilacija hrvatskih Židova, 1900-1971 [Language assimilation of Croatian Jews, 1900-1971] (Goldstein 2004: 19). 
1872) became Dimitrija Demeter, Ignatius Fuchs (1819-1854) from a Germanspeaking Jewish family became Vatroslav Lisinski (Croatian vatra 'flame', lisica 'fox'; -slav < PS. slava 'glory' is a typical Slavic ending), and Ferdinand Wiesner (1799-1879) became Ferdo Livadić (Croatian livada 'meadow').

There are two questions that this paper is going to try answering:

1) Did Zagreb Jews follow the trend of adopting more Slavic and Croatian names during the period in question?

2) Did Slavic and Croatian names appear among feminine names earlier than among masculine ones, as is usually the case in Jewish communities whose anthroponymy have been researched (Colorni 1983; Beider 2001)?

\section{Sources}

There are three sources of data that were used for this research.

In 1939, Rabbi Gavro Schwarz published the book Povijest zagrebačke židovske općine od osnutka do 50-tih godina 19. Vijeka [The history of the Jewish community in Zagreb since its foundation until the 1850s], that contains several lists of Zagreb Jews: the first census of Jews under the municipal jurisdiction from the year $1808^{5}$ (Schwarz 1939: non-paginated insert between pp. 8 and 9), the first census of Jews under the bishopric jurisdiction from the year 1812 (Schwarz 1939: 13), the list of Zagreb Jews from the years 1840-1843 (Schwarz 1939: 45-76) and the alphabetical list according to the conscription from the year 1858, before the introduction of official registries (Schwarz 1939: 76-93).

In the Croatian State Archives Jewish birth registries from the years 1849 to 1898 (with the omission of the year 1857) are deposited. For the years 1859 to 1870 there are parallel records in two registries, with different forms and written by different hands (Matične knjige rodenih). Both data of the newborn children and of their parents are taken into consideration.

The Jewish (Israelite) section of the Old Cemetery at Mirogoj occupies thirteen fields at its south-western end as well as three southern pavilions (9157) and three fields (924) of the arcade along its western edge. Along with Latin (both German and Croatian) and Hebrew inscriptions on headstones, more data are available from the database accessible on-line via the browser at the Municipal Cemeteries Internet site (Gradska groblja).

Gavro Schwarz's book lists 1,213 individuals, the birth registries 3,975 individuals and all the data collected from sources concerning Mirogoj 2,340 individuals. When data from different sources are combined, 6,600 individuals occur, of which 4,097 have known first name(s), family name(s) and year of birth.

The problems that arise with this corpus are:

1) There is no fixed first name. The same person appears under different

5 Schwarz in one location mistakenly quotes 1908 as the year when the census was made (Schwarz 1939: 10); however, in the following text he mentions the correct one, 1808. 
first names in different sources. ${ }^{6}$ While variations of the type Franziskal Franciska/Fanike/Fanika/Fany/Fanni/Fani are easy to explain, those of the type Amalie/Amalia/Emilija/Minna/Mina are harder to discern and can be detected only by meticulously comparing other data concerning the individual in question.

2) Sometimes even the family name seems not to be fixed. In some entries in the birth registries the child and the parents bear family names that differ mostly by suffix, e.g. -berg vs. -berger. The puzzling fact is that both these family names seem to be written by the same hand, supposedly at the same time. When comparing different sources even more discrepant data appear, e.g. Rosendorfer/ Rogendorfer/Ragendorfer or Rosenfeld/Rosenthal.

3) The on-line database of Gradska groblja contains lots of typos due probably to the fact that the person(s) entering the data were unfamiliar with the handwriting of the epoch, both the Cursive Gothic script and the Latin cursive one and their mixes and combinations. However, some first names like BERUHARD and family names like KANDERS are easy to interpret as Bernhard and Kauders, respectively. ${ }^{7}$

\section{Analysis}

Under the term "civic" name are collected the official names used by the civic authorities, written in Latin script, while the phrase "Judaic" name covers all the names written in Hebrew script ${ }^{8}$ as used in Jewish ritual within the Jewish community and in Hebrew documents. The distribution does not coincide with the division into life, and for all the religious and ritual purposes, respectively.

\section{1. "Civic" names of Zagreb Jews}

Among the "civic" masculine names of Zagreb Jews in all the sources two are dominant above all others: Josephus/Joseph/Josef/Jozef/Josip/Jožek/ Josif/Josel/Jos./Guseppo and Jacobus/Jacob/Jaco/Jac./Jakob/Jakov/Jakel/Jak./ Jacques/Jacqes/Jaques/Žak/James, names derived from Hebrew names יוֹסֵ

6 An explanation of this might be found in Beider (2012).

7 The data from the Gradska groblja on-line database are given in all caps as they are entered in the database itself.

8 With three exceptions: Abraham (45/1892),Elasar (1066/1884), and Eszter (76/1897). However, all three of them were entered in the rubric provided for the registration of the "Judaic" first name, patronymic (exceptionally metronymic) and Jewish date of birth of the newborn in the registries, beside their "civic" first names: Albert, Vladko, and Terezija, respectively. 


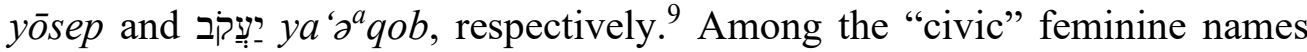
there is more variety among the most popular ones, but some trends are discernible: internationally popular names $(<R o s a)$, names derived from

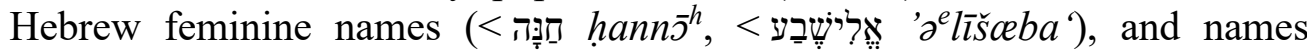
derived from Hebrew masculine names (< < ידוֹ

What might be the reason for such a popularity of the two abovementioned masculine names? One explanation may be that in a Catholic surroundings, as Zagreb was, where New Testament and saints' names were

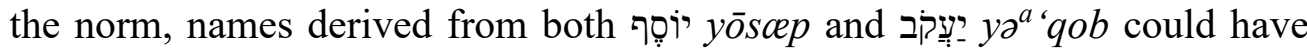
functioned well as both typical Jewish names and as usual names of Catholics, so their bearers could assimilate more easily into a non-Jewish setting. Reasons for this desire might be purely business ones. ${ }^{10}$

In analysing the etymologia remota of "civic" Jewish names, the languages or groups of languages in which the names originated, it turns out that the names of $3.80 \%$ of men and of $10.06 \%$ of women are of unknown origin. Those are mostly nicknames, hypocoristics and pet names elevated to the status of full names, whose origin cannot be asserted with certainty. The frequency of the individuals with names of known origin is represented in Figure $1 .^{11}$

The percentage of men with Slavic names $(10.85 \%)$ is a little higher than that of women (7.68\%). Also, among men, Slavic names are the fourth most frequent, while among women they are the fifth one. As far as the number of individuals with names of Slavic origin is concerned, these seem to be more popular among men than among women.

9 To illustrate their dominance, in Schwarz's book there are 56 Josephus/Joseph/Josef/ Jozef/Josel/Josip/Jos. and 48 Jacobus/Jacob/Jakob/Jacques/Jakov/Jaco/Jac., while the three third-positioned names have only 29 bearers each; in the birth registries there are 119 Jacob/Jakob/Jakov/Jakel/Jacques/Jaques/Jak. and 113 Joseph/Josef/Jozef/Josif/Josip/ Guseppo/Jos., while the third-positioned name has only 93 bearers; in the data from Mirogoj there are 108 Josef/Josip/Jožek/JOZEF/Jos. and 78 Jacob/Jakob/Jakov/Jaques/ Jacqes/ŽAK/James, while the third-positioned name has 77 bearers.

10 Ljiljana Dobrovšak wrote in her master's thesis about the changes of Jewish family names for economic reasons (Dobrovšak 2003: 159).

11 In these figures names of Latin origin are separated from those of Romance origins, as Latin is not considered one of the Romance languages, but in its later Vulgar Latin variant as the Romance proto-language. The only masculine first name of Celtic origin appearing in the corpus was the Irish first name Oscar. The first name Arthur that also appears in the corpus is often claimed to be a Celtic one but its origin and etymology are still disputed. The only masculine first name of Turkic origin appearing in the corpus was the Bulgar first name Boris. The only masculine first name of Persian origin appearing in the corpus was the first name Mirza. The name Malvina of poetic origin was created by the 18 th century Scottish poet James Macpherson (1736-1796) in his Ossianic poems. 


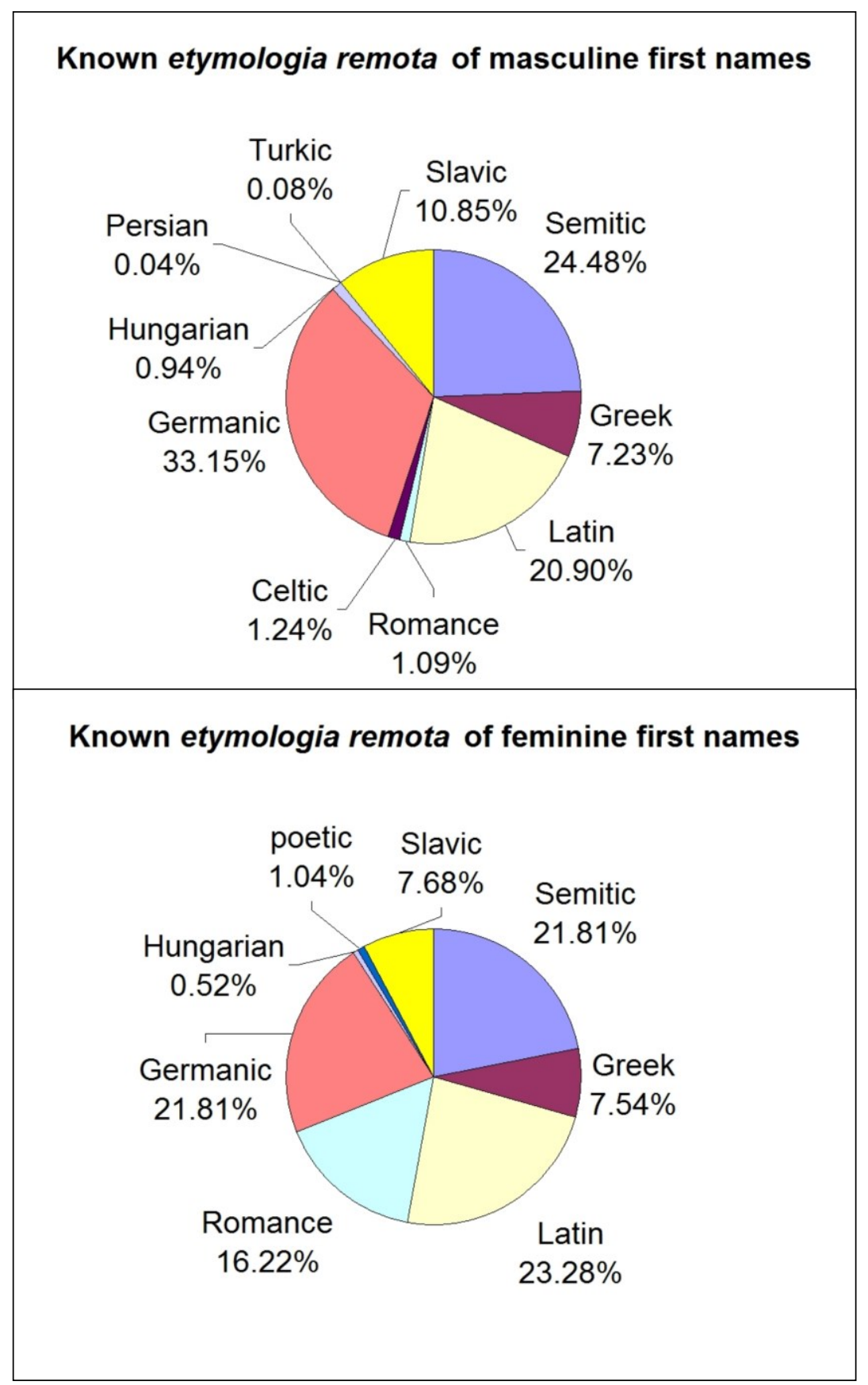

Figure 1: Percentage of bearers of "civic" names of known etymologia remota

If we ignore the number of individual bearers and concentrate instead only on the etymologia remota of different forms of first names, the percentage of those of unknown origin becomes evidently larger among feminine names $(20.5 \%)$ than among masculine ones $(8.26 \%)$. The frequency of the name forms of known origin is represented in Figure 2. 


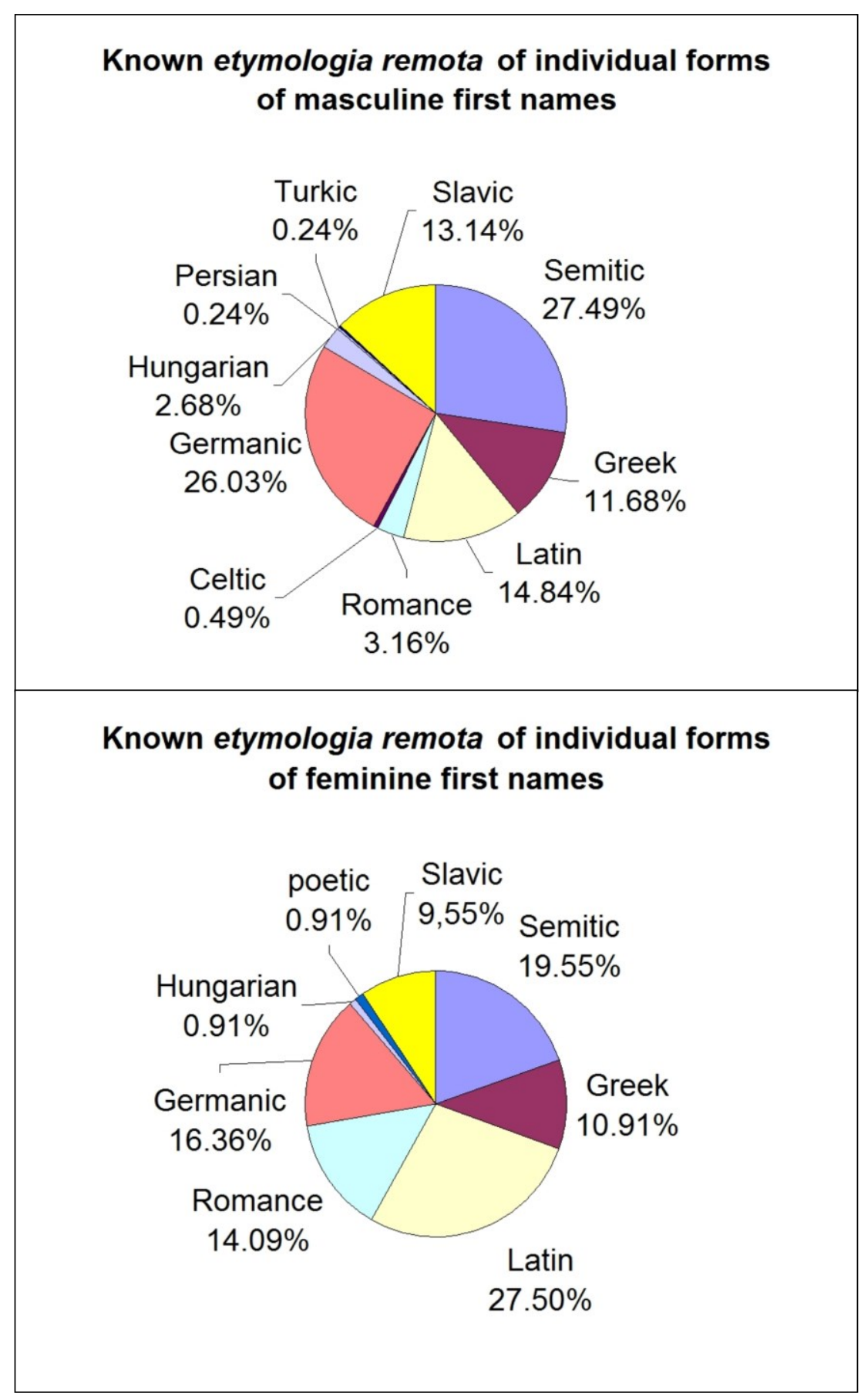

Figure 2: Percentage of "civic" name forms of known etymologia remota

Again, the percentage of Slavic name forms is greater among the masculine names $(13.14 \%)$ than among the feminine ones $(9.55 \%)$, although the difference 
is not significant. Slavic name forms are the fourth most popular among masculine names, but only the sixth most popular among the feminine ones.

Diachronically, the first masculine name of Slavic origin, Lavoslav, the folk translation of Leopold, appeared in 1859. The first feminine name of Slavic origin, Ljuba, appeared five years later, in 1864. In both cases the names of Slavic origin reached their maximum in 1897, with 14 men and 9 different masculine names (Božidar, Dragutin, Lavoslav, Ljudevit, Milan, Radivoj, Srećko, Stanko, Vladimir) as well as 11 women and 8 different feminine names (Darinka, Dragica, Jelka, Ljudevita, Nada, Vera, Zdenka, Zora). In the last year for which we dispose of the data needed, 1898, 33.33\% of all the individual men bore names of Slavic origin, $20 \%$ bore names of Latin as well as Germanic origin, and $13.33 \%$ bore names of Semitic as well as Greek origin. In the same year, $29.41 \%$ of all the individual women bore names of Latin origin, $23.53 \%$ bore names of Slavic as well as Semitic origin, $17.65 \%$ bore names of Germanic origins and 5.88\% bore names of Greek origin.

In analysing the etymologia proxima of "civic" Jewish names, the languages from which the names were directly borrowed, the number of unknown languages is considerably higher: only $6.49 \%$ individuals with masculine names but $62.89 \%$ individuals with feminine ones. Together with nicknames, hypocoristics and pet names elevated to the status of full names there are also many names for which it is not possible to trace the languagemediator, because their forms are the same in many languages, e.g. Adam or Anna. The frequency of the individuals with names of known origin is represented in Figure 3. ${ }^{12}$

The percentage of men with German names (51.45\%) and that of women with German ones (49.88\%) is almost the same. Similarly, this can be said, to a slightly lesser degree, for Croatian masculine names (38.11\%) and Croatian feminine ones $(32.29 \%)$. In both cases the percentage of masculine names is slightly bigger than that of feminine ones.

12 The only masculine first name borrowed from Polish appearing in the corpus was the first name Ignacy. The only feminine first name borrowed from Russian appearing in the corpus was the first name Olga, derived from the Norse first name Helga. The only feminine first name borrowed from Polish appearing in the corpus was the first name Bronia, derived from Bronistawa. 


\section{Known etymologia proxima of masculine first names}

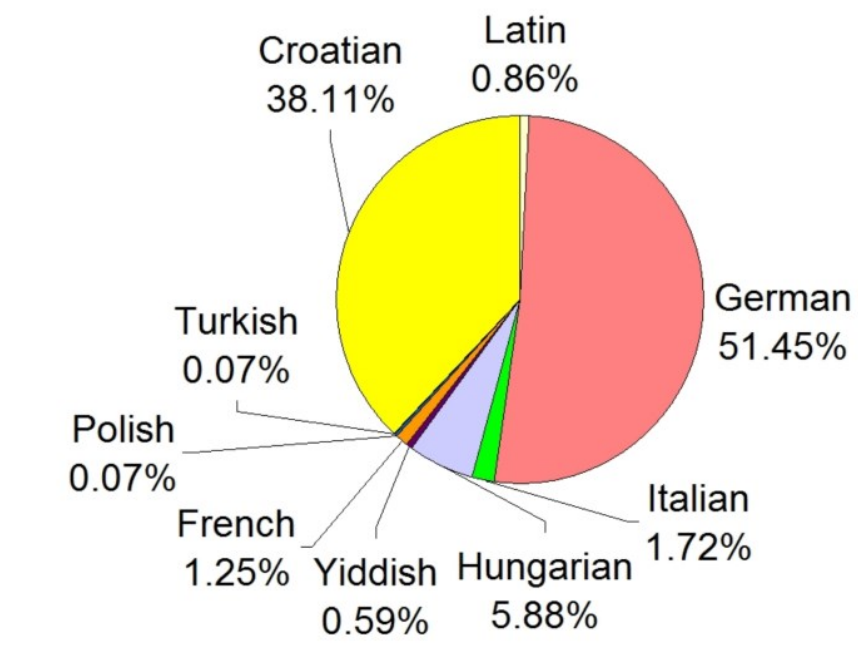

\section{Known etymologia proxima of feminine first names}

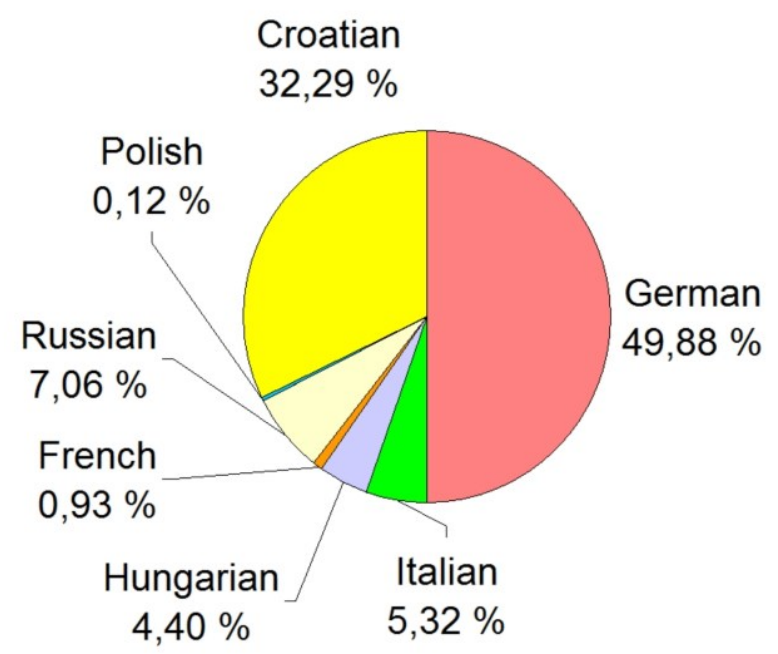

Figure 3: Percentage of bearers of "civic" names of known etymologia proxima

If we ignore the number of individual bearers and concentrate instead only on the etymologia proxima of different forms of first names, the percentage of both masculine and feminine names of unknown language-mediator takes more than half of all names, $55.8 \%$ and $67.47 \%$, respectively. The frequency of the name forms of known language-mediator is represented in Figure 4. 


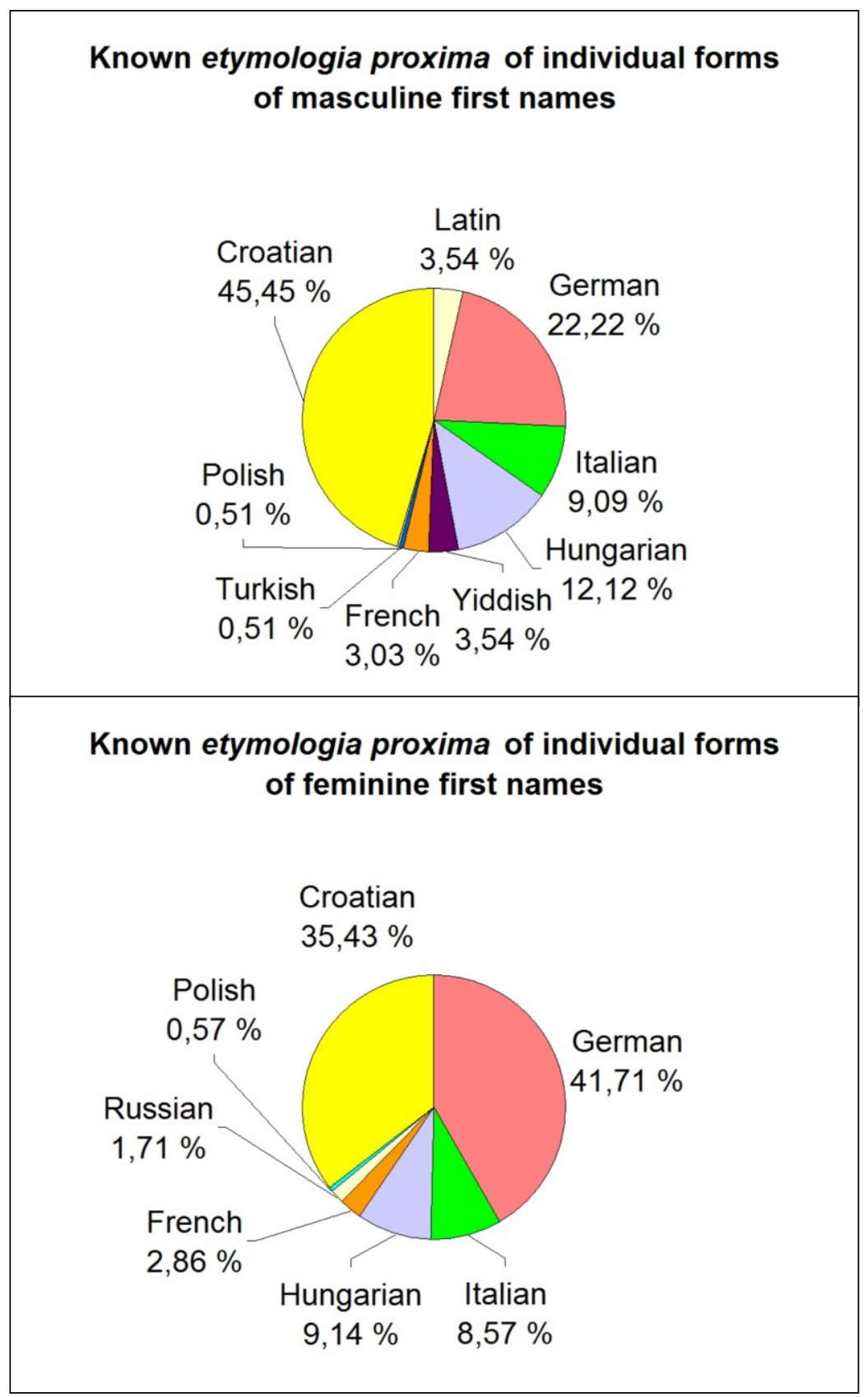

Figure 4: Percentage of "civic" name forms of known etymologia proxima

Among the masculine name forms, the percentage of Croatian ones $(45.45 \%)$ is twice the one of German ones $(22.22 \%)$. Among the feminine name forms their order is reversed, the percentage of the German name forms $(41.71 \%)$ being only slightly higher than the one of the Croatian name forms $(35.43 \%)$. 
Chronologically, the first Croatian masculine name, Hinko, the Croatian version of the German Heinrich, appeared in 1825. The first Croatian feminine name, Judita, the Croatian version of the Hebrew יהוּ? twenty-five years later, in 1852. In both cases Croatian names reached their maximum in 1897, with 17 men and 11 different masculine names (Božidar, Dragutin, Ivo, Lavoslav, Ljudevit, Milan, Pavao, Radivoj, Srećko, Stanko, Vladimir) as well as 19 women and 13 different feminine names (Darinka, Dragica, Jelisava, Jelka, Ljudevita, Marija, Nada, Roza, Ruža, Terezija, Vera, Zdenka, Zora). In the last year for which we have the needed data, 1898, $91.91 \%$ of all men bore Croatian names, while the remaining $9.09 \%$ bore Italian names. In the same year, $78.57 \%$ of all the women bore Croatian names, $14.29 \%$ bore Russian names, and $7.14 \%$ bore Italian names.

It is obvious that during the period researched, the Slavic and Croatian names were on the rise at the expense of the Germanic and German ones. If there were more accessible data for the 20th century, the trend would probably continue at the same pace at least, if not faster.

How to explain the fact that masculine Slavic and Croatian names appeared before feminine ones and that such names were more popular among men than among women? The supposed reasons may be business and economic ones again. The male Jewish population held occupations that brought them into contact with the outside, non-Jewish world, where a non-Jewish name could be more advantageous than an overtly Jewish one. On the other hand, women stayed at home, probably socialising with other Jewish women and not having intensive contacts with the gentile world outside the community.

\section{2. "Judaic" names of Zagreb Jews}

Of the eleven most popular "Judaic" masculine names of Zagreb Jews ${ }^{13}$ ten

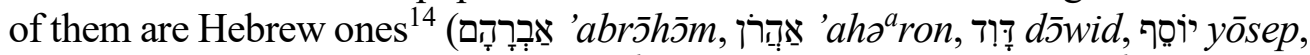

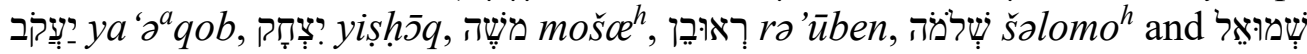
šzmu' 'el) while only one is a Yiddish name (ליב leyb). On the other hand, of the eleven most popular "Judaic" feminine names ${ }^{15}$ only seven are Hebrew ones

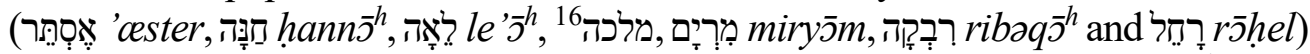

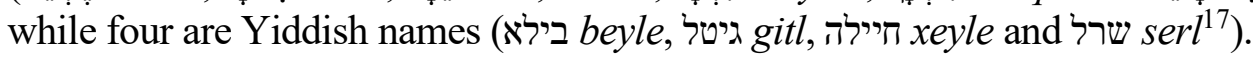

13 And at the same time the only ones having more than ten bearers.

14 Or variants thereof.

15 And at the same time the only ones with ten or more bearers.

16 This name can be interpreted either as the post-Biblical name malk $^{h}$ or as the Biblical

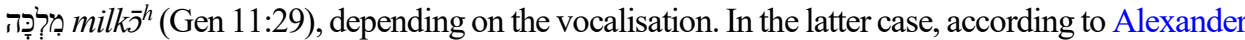
Beider (2001: 542), a contamination may have occurred with the Slavic name Milka < mil'nice' + -ka (diminutive suffix), which might have influenced its popularity in Slavic countries.

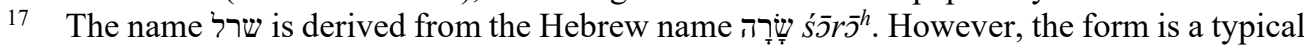
Yiddish diminutive one with Umlaut: Sare/Sore > Serl (Beider 2001: 574-578), this being the main reason that it is included among the Yiddish names. 
The frequency of the analysed "Judaic" names, is represented in Figure $5 .{ }^{18}$

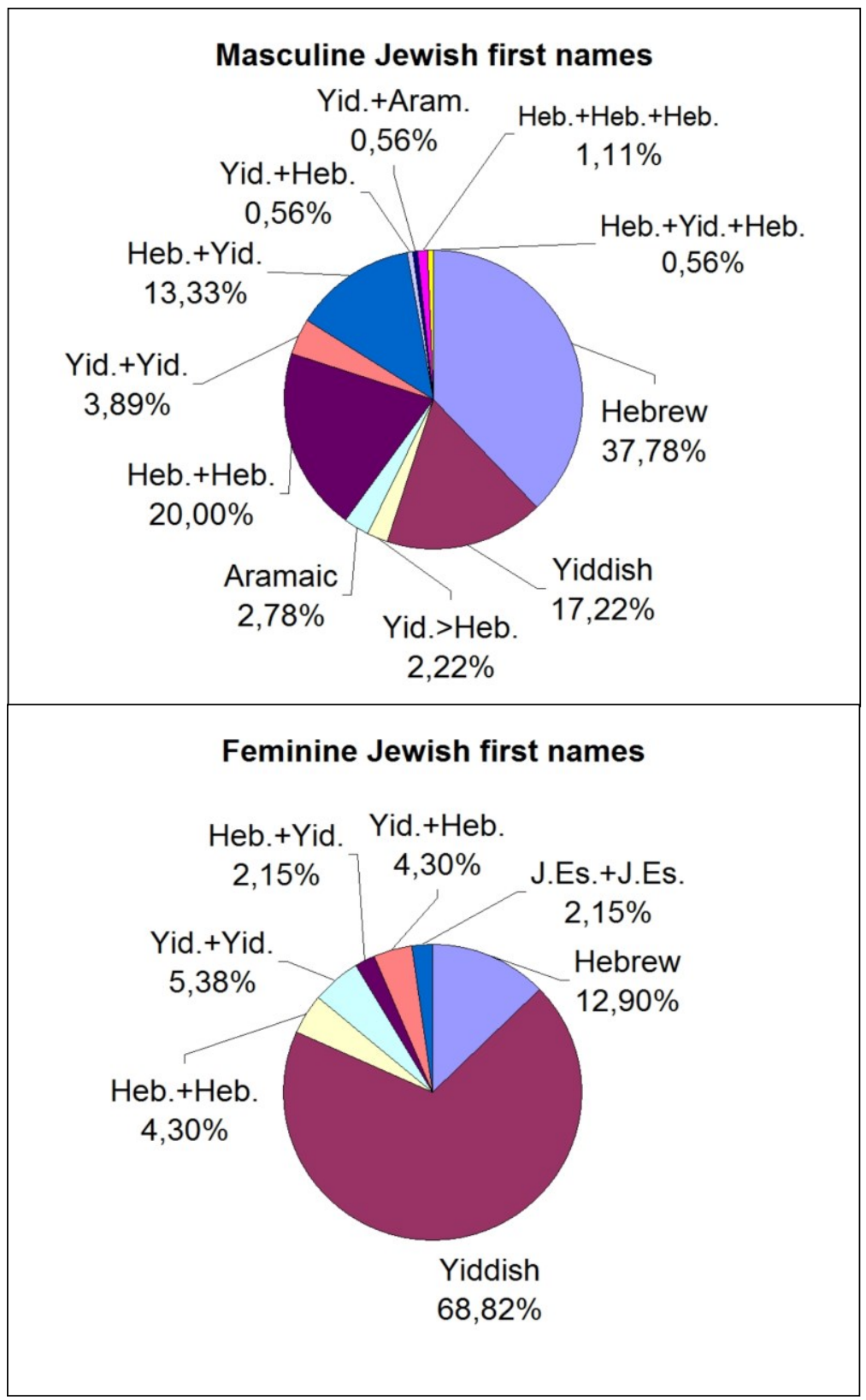

Figure 5: Percentage of "Judaic" name forms by language

18 Alexander Beider mentions that Yiddish variants of the metaphorical (animal) names from the Blessing of Jacob from Genesis 49 appeared among the Jews of Central and Eastern Europe before their Hebrew counterparts, making the latter a re-translation of the former (Beider 2001: 277-278, 296, 434, 463; 2012: 53, endnote 16). 
It is immediately noticeable that Hebrew names are the most popular masculine ones, while among the feminine names Yiddish ones represent more than two thirds of all the names. Among masculine names there are more combinations of two Hebrew names than a single Yiddish one. Moreover, in pairs consisting of a Hebrew and a Yiddish name the former is almost always the first in the pair, there is just one example of a reverse order of names (חיז hann $\bar{s}^{h}$ elya). ${ }^{19}$ On the other hand, among feminine pairs of names in the sources there are more combinations in which the Yiddish name comes first, followed by the Hebrew one. ${ }^{20}$

If we take a look at the number of individuals bearing a name of certain origin, the situation is represented in Figure 6.

Again, it is evident that more than half of men (58.03\%) bear Hebrew names, while more than half of women $(54.19 \%)$ bear Yiddish ones. ${ }^{21}$ While men with Yiddish names, the second most frequent population, make just $10.16 \%$ of their total number, the number of women bearers of Hebrew names in their second position is $40.50 \%$. While bearers of those two groups of names constitute only two thirds among the men, they form almost $95 \%$ among the women. ${ }^{22}$

19 There is also one example of a pair of names in which the Yiddish one comes before the Aramaic one: פיישל שִ feyšl šaraḡ̄o '.

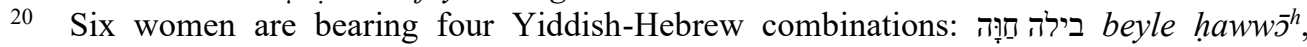

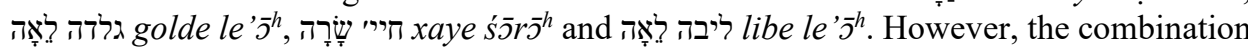

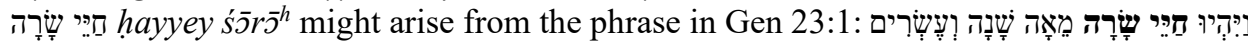

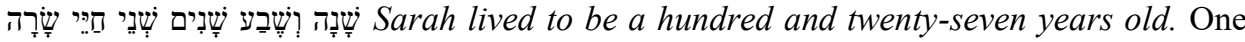
woman is bearing a Hebrew-Yiddish combination: מִרְִיָם חיילה miry meym xeyle. One

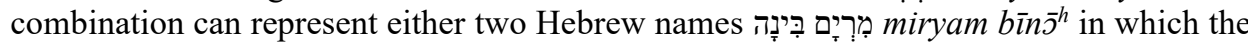
nמרְיָם בינה mirȳ̄m bine in which the name בינה bine is derived from the Romance one meaning 'good' (Beider 2001: 487-488).

21 The prevalence of Hebrew first names for men is directly related to the Jewish tradition of

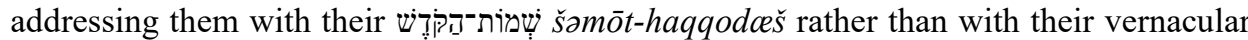
names within the community. There is no such dichotomy for feminine first names. However, Jewish women are mentioned in Jewish sources by names used internally by the community, not by those used in their contacts with gentiles (Beider 2012: 44).

22 The four most popular groups of "Judaic" names among individuals comprise $71.15 \%$ of all the men, but $97.21 \%$ of all the women. 


\section{Individuals with masculine Jewish first names}

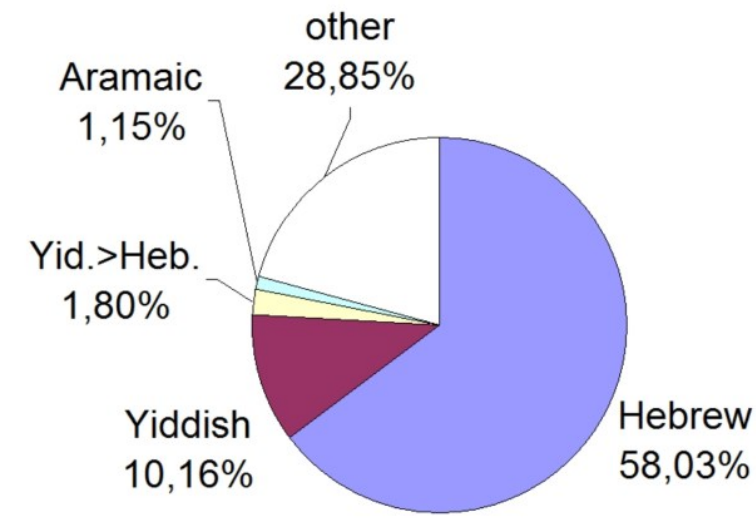

Individuals with feminine Jewish first names

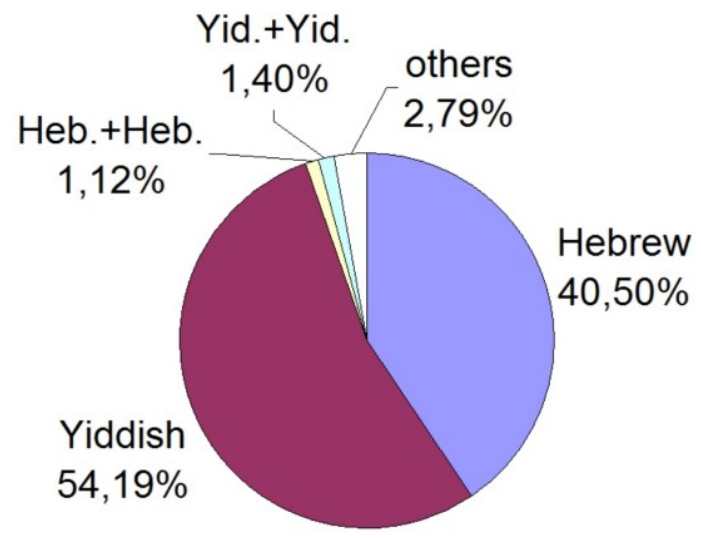

Figure 6: Percentage of bearers of "Judaic" name forms by language

\subsection{Correlations between "civic" and "Judaic" Names}

Three principles of pairing a "civic" and a "Judaic" name are discernible among the masculine ones (Colorni 1983: 71). Most pairs demonstrate a phonetic 
affinity -21 of them. ${ }^{23}$ They either begin with the same sound or contain the same combination of two or three consonants or homorganic consonants in the same order. There are even some examples of not so obvious phonetic connections: the pair

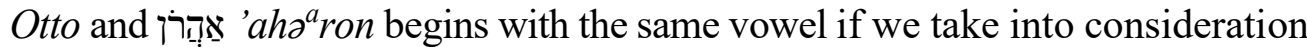
the Yiddish pronunciation of the Hebrew name Orn (Beider 2001: 394-396). If we know that in the translations of the Bible into European languages the

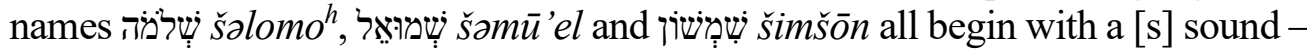
Salomon, Samuel and Samson, respectively - the pairings Sigmund and

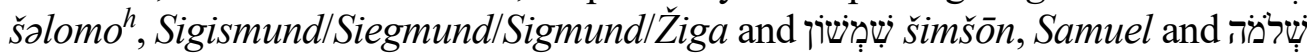
šalomo ${ }^{h}$, as well as Siegmund/Žiga and If we stretch the criteria a bit, we can also include the pair Heinrich and

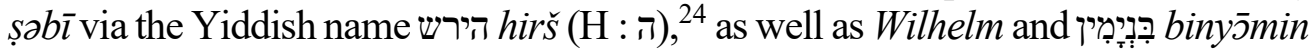
via the Yiddish name וואלָ wolf (וו : the first consonant not of the Hebrew name itself but of its kinnuy

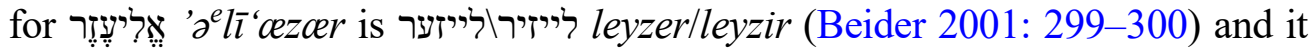

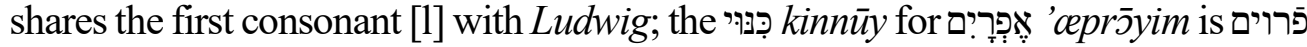
froym (Beider 2001: 298-299) and it shares the first consonant [f] with Ferdinand (moreover, they both share a [r] as well). The name Emanuel shares the sounds

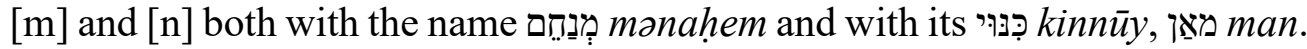

Pairings motivated by Jacob's Blessing in Genesis 49 comparing Judah and the lion (Gen 49:9) give us the bi-names: Leopold ${ }^{26}$ and ליב $y \partial h \bar{u} d \bar{s}^{h}$, Leo and ליב 'arye leyb, and Leopold and the Hebrew word for 'lion':

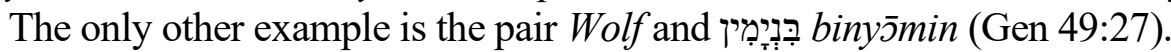

The third principle, translation, is often combined with folk etymology, as already demonstrated in the name Leopold. However, there are also some real translations, as the abovementioned Leo, but also in the pair Bernhard ${ }^{27}$

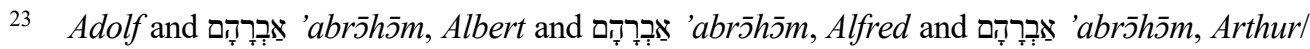

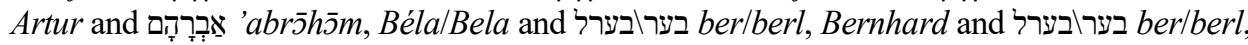
Emanuel and מענדל מפיישל feysend, Franz/Frany/Franjo and

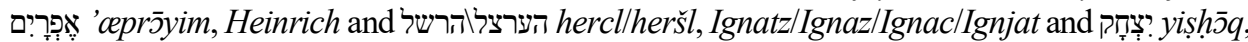

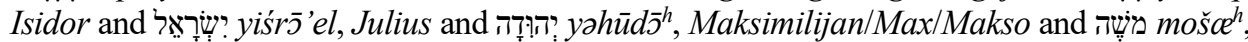

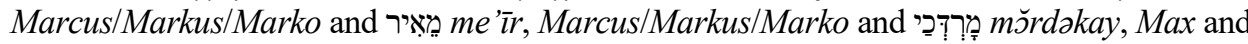

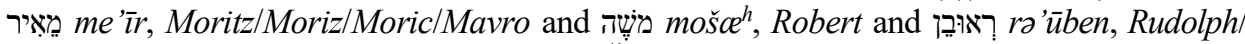

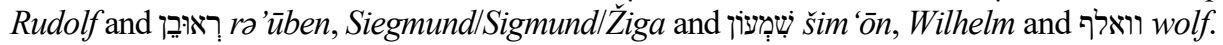

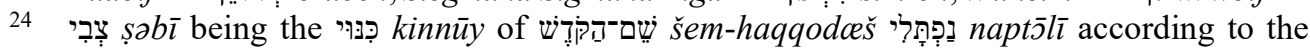
Blessing of Jacob in Gen 49:21.

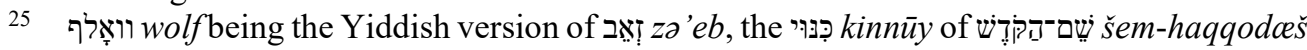

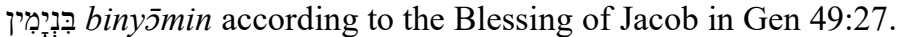

26 Leopold has nothing to do with the Latin word leo, but originates from Proto-Germanic*leudi'man, people' + *balp/da- 'brave' (Kroonen 2013: 50, 332). The connection is pure folk etymology.

27 From Proto-Germanic *beran- 'bear' + *hardu- 'hard, severe' (Kroonen 2013: 59-60, 211). The combination of the Hebrew name is a variation of the Blessing of Jacob for that tribe (Gen 49:14). Originally the animal

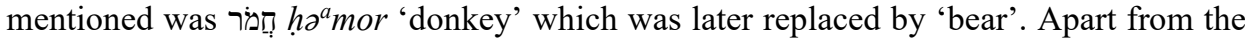
unflattering connotations that a 'donkey' might induce in a European setting, the 
and בער|בערל ber/berl.

However, there is a fourth principle of pairing present among the masculine name pairs, not mentioned by Vittore Colorni: the original Hebrew name and its form in some other language (Beider 2012: 49): Joseph/Josef/Josip and יוֹ

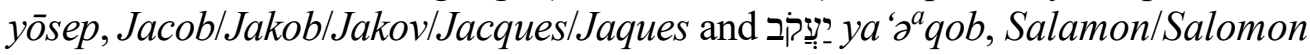

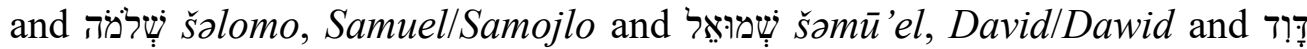

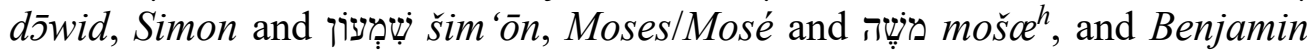

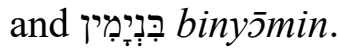

Among feminine name pairs the only principle for pairing them is phonetic affiliation: identical first sound ${ }^{28}$ of the names or containing the same combination of two or three consonants or homorganic consonants in the same order. ${ }^{29}$ However, the number of women with known both names (356) in the corpus is considerably smaller than that of the men (605).

The question arises whether fixed pairs of a "civic" and "Judaic" name are diachronically stable or is their diachronic frequency falling or rising. This is a question to which no unambiguous answer can be given.

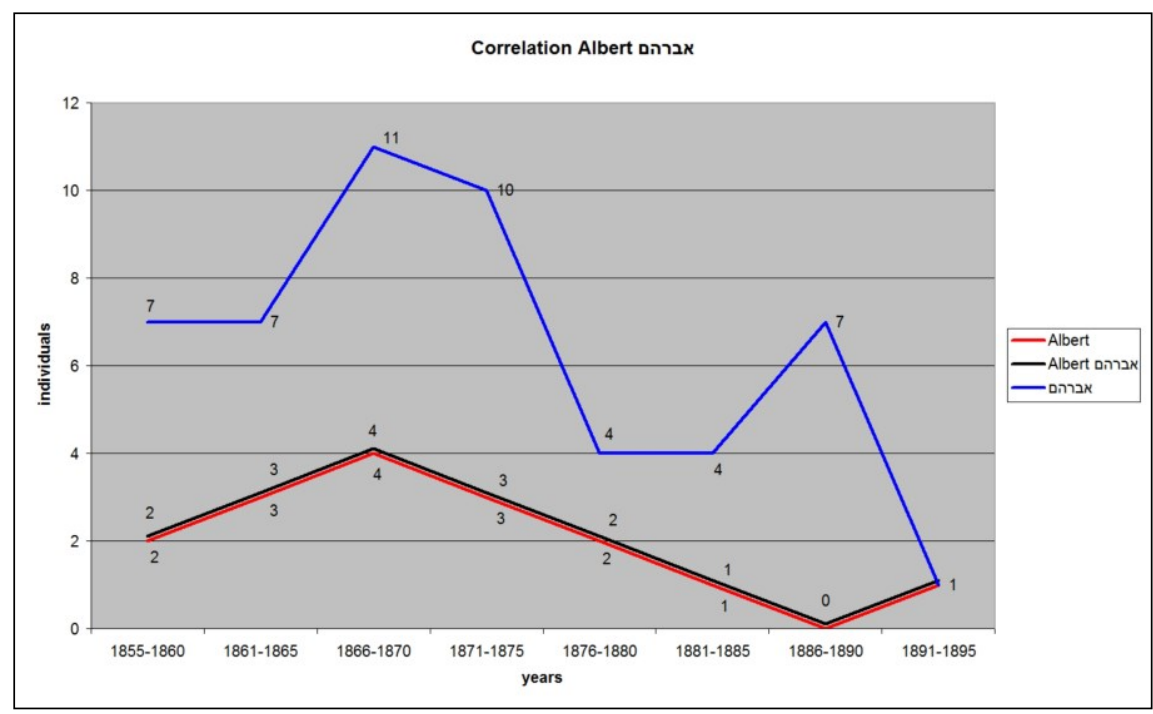

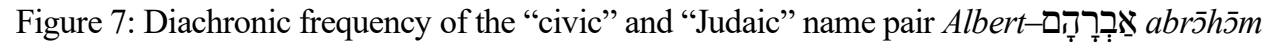

replacement might have been also caused by the fact that the individual who raped Dinah in Gen 34:2 was

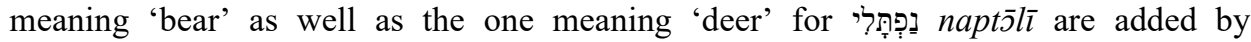
Ashkenazim to the two other names inspired by Jacob's blessing that were in use in

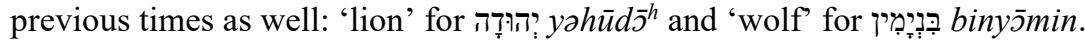

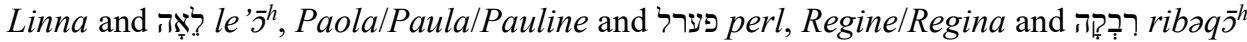

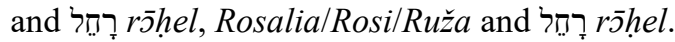

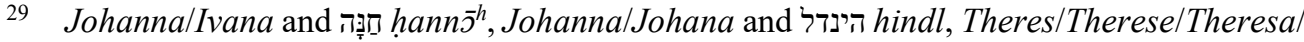
Theresie/Terezija and Rosa and שרל serl, although the sequence of common consonants is not the same. 


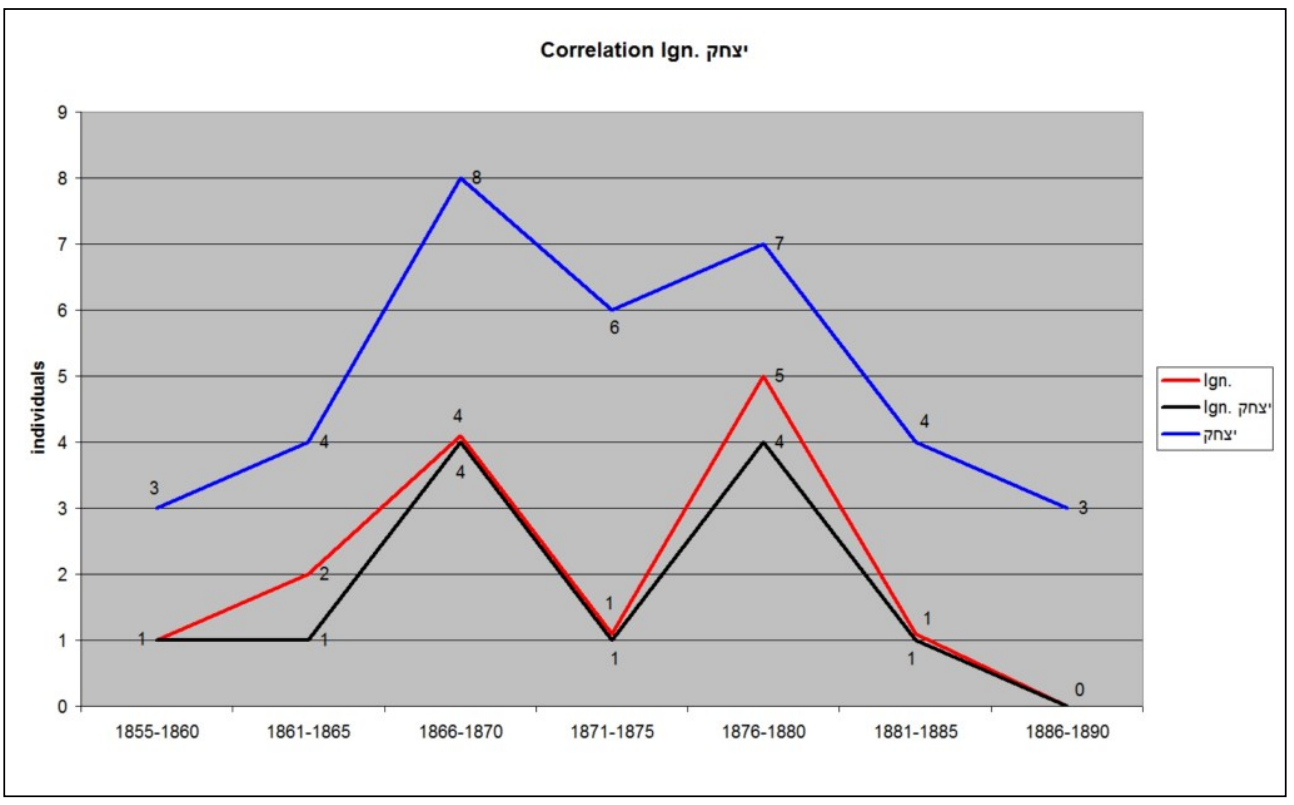

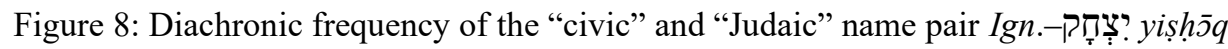

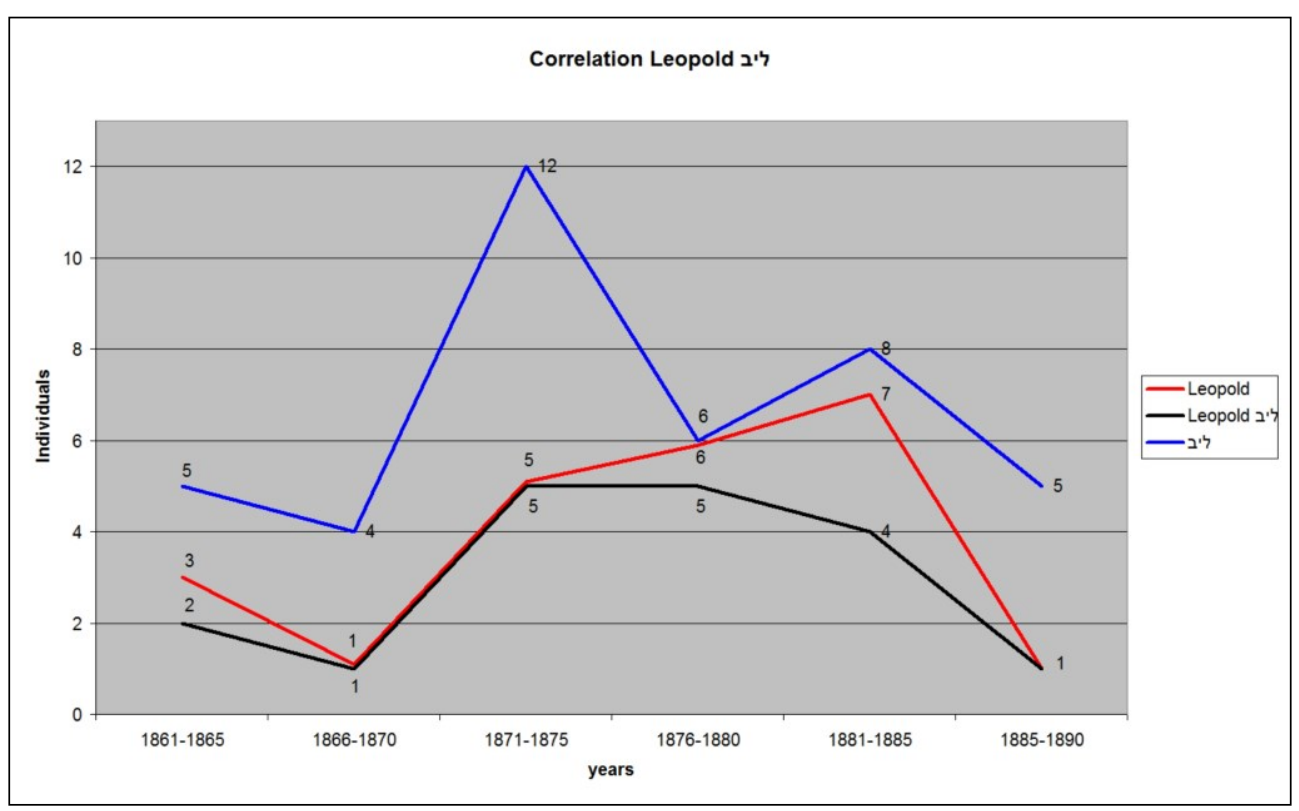

Figure 9: Diachronic frequency of the "civic" and "Judaic" name pair Leopold-ליב leyb 


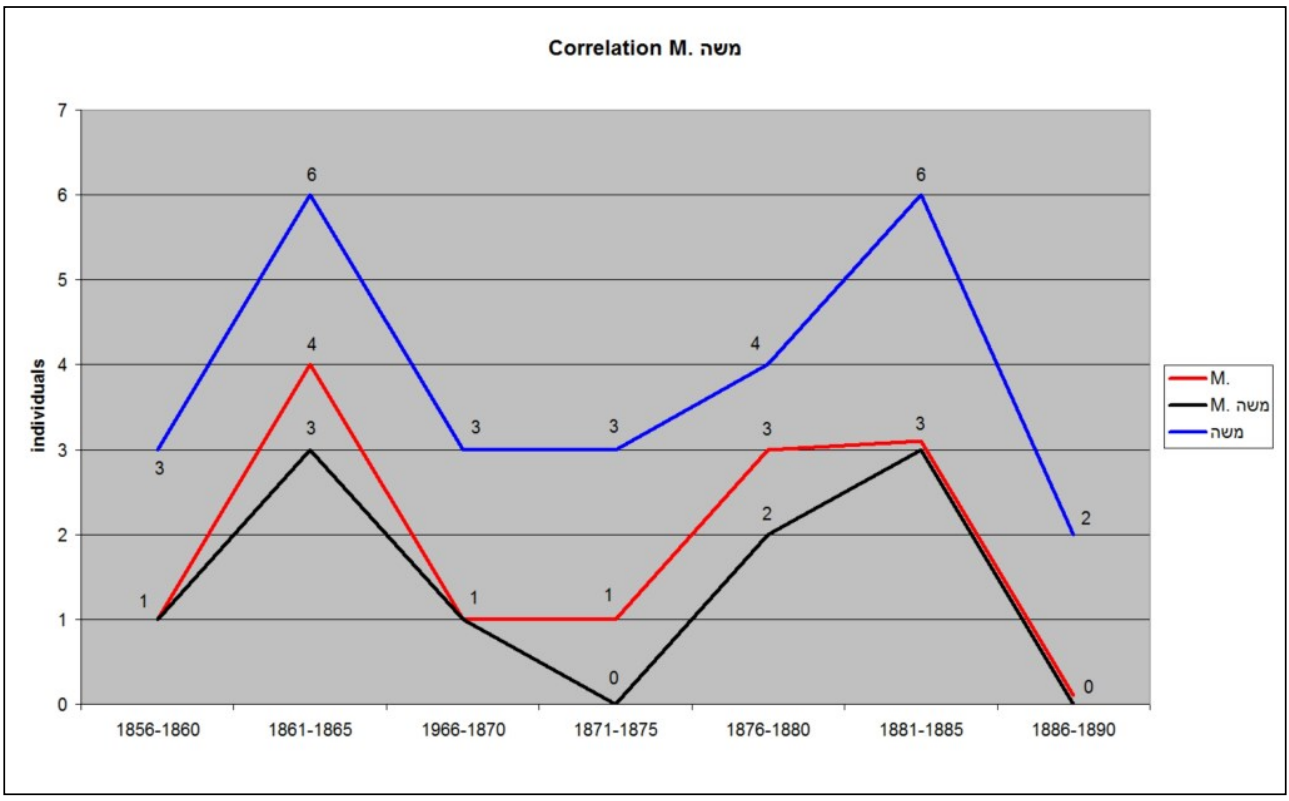

Figure 10: Diachronic frequency of the "civic" and "Judaic" name pair M.-השֶׁה moš $e^{h}$

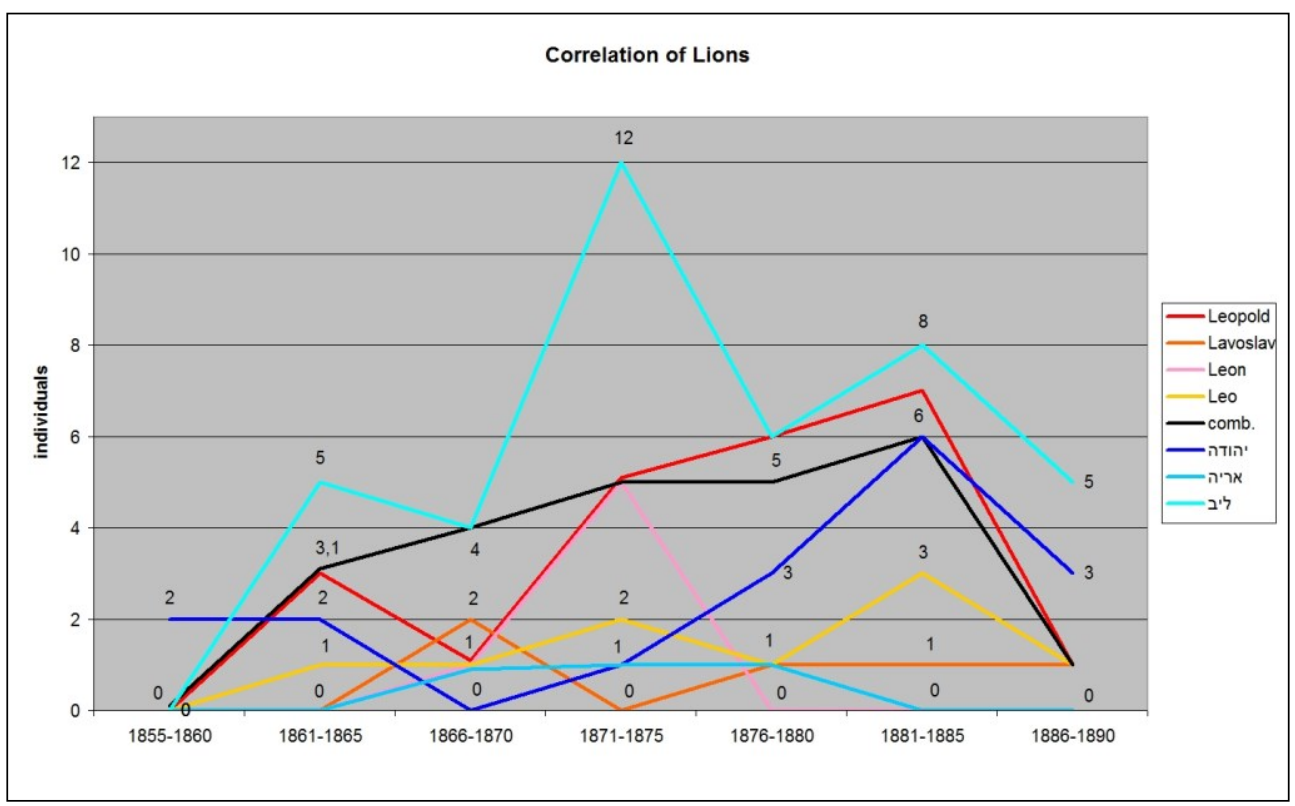

Figure 11: Diachronic frequency of the "civic" and "Judaic" name pair concerning 'lions'

There are various trends going on in various name pairings. The

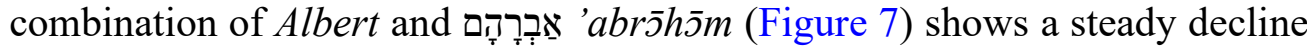
in numbers from the maximum of 4 in 1866-1870 until the end of the century. On the other hand, the combination of "civic" names Leopold, Lavoslav, Leon 


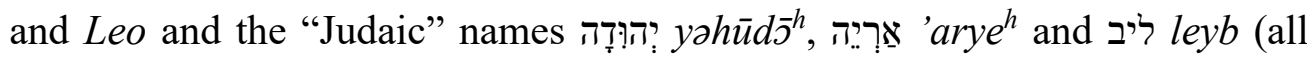
connected by the meaning 'lion'; Figure 11) is on a continual rise from 18551860 until its maximum of 6 in 1881-1885. The other combinations, Ignatz,

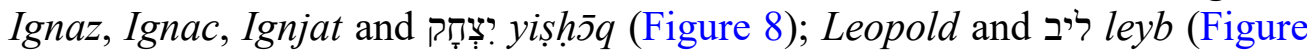
9); and Moritz, Moriz, Moric, Mavro and משֶׁ moš $e^{h}$ (Figure 10), demonstrate a rather stable situation. (It must be taken into consideration that the data for fringe pentads are scarcer than for other ones.) Considering the available data, the answer to that question remains inconclusive.

\section{Conclusion}

Zagreb Jews did follow the trend of adoption of Slavic and Croatian names which increased during the period in question, at the expense of the Germanic and German ones.

However, Slavic and Croatian names did not appear among feminine names earlier than among masculine ones, nor were they more frequent among women than among men, as is usually the case in Jewish communities whose naming patterns have been researched. The situation in Zagreb seems to indicate the contrary, possibly due to interaction with their gentile neighbours in economic and social affairs.

\section{Aknowledgments}

I want to thank Dr. Aaron Demsky and Dr. Alexander Beider whose advices and suggestions helped me in writing this paper with as few mistakes and inaccuracies as possible.

\section{References}

Beider, Alexander. 2001. A dictionary of Ashkenazic given names: their origins, structure, pronunciation, and migrations. Bergenfeld, NJ: Avotaynu.

Beider, Alexander. 2012. Discontinuity of Jewish naming traditions. Avotaynu vol. XXVIII, n. 2, pp. 43-53.

Brandl, Naida Mihal. 2015. Židovi u Hrvatskoj od 1944./5. do 1952 [Jews in Croatia from 1944/5 until 1952]. Zagreb: Faculty of humanities and social sciences. (Unpublished doctoral disertation.)

Colorni, Vittore. 1983. La corrispondenza fra nomi ebraici e nomi locali nella prassi dell'ebraismo italiano [The correspondence between Jewish names and local names in the practice of Italian Judaism]. In Italia judaica. Atti del I Convegno internazionale, Bari 18-22 maggio 1981, 67-86. Rome: Ministry of cultural heritage and activities. 
Dobrovšak, Ljiljana. 2003. Hrvatska javnost prema Židovima krajem 19. stoljeća (za vrijeme Dreyfusove afere od 1894.-1899.) [The Croatian public towards Jews at the end of the 19th century (during the Dreyfus affair from 1894-1899)]. Zagreb: Faculty of humanities and social sciences. (Unpublished masters' dissertation.)

Goldstein, Ivo. 2004. Židovi u Zagrebu 1918-1941 [Jews in Zagreb 19181941]. Zagreb: Novi Liber.

Gradska groblja. 2014. Tražilica pokojnika [Search engine for the deceased]. Zagreb: Gradska groblja. (https://www.gradskagroblja.hr/trazilicapokojnika/15) (Accessed 2016-08-01).

Kronologija židovstva u Hrvatskoj [Chronology of Judaism in Croatia]. Jewish Community of Zagreb. (https://www.zoz.hr/hr/) (Accessed on 2016-3-14).

Kroonen, Guus. 2013. Etymological dictionary of Proto-Germanic. Leiden, Boston: Brill.

Matične knjige rođenih 1849-1870 Židovske općine Zagreb [Birth registries 1849-1870 of the Zagreb Jewish Community]. Croatian state archive.

Schwarz, Gavro. 1939. Povijest zagrebačke židovske općine od osnutka do 50tih godina 19. vijeka [The History of the Jewish Community in Zagreb since its foundation until the 1850s]. Zagreb: Štamparija Gaj. (http://www.ffzg. unizg.hr/judaistika/wp-content/uploads/2018/01/Schwarz.pdf) (Accessed 2021-12-12.) 


\section{Appendices}

\section{Appendix A: Transliteration of Hebrew names and words}

\begin{tabular}{|c|c|c|}
\hline $\begin{array}{c}\text { square } \\
\text { script }\end{array}$ & transl. & \\
\hline א & , & \\
\hline ב & $b$ & \\
\hline$\lambda$ & $\mathrm{g}$ & \\
\hline 7 & $\mathrm{~d}$ & \\
\hline \multirow[b]{2}{*}{ ה } & $\mathrm{h}$ & \\
\hline & $\mathrm{h}$ & $\begin{array}{l}\text { silent at } \\
\text { end of word }\end{array}$ \\
\hline 1 & $\mathrm{w}$ & \\
\hline$i$ & $\mathrm{z}$ & \\
\hline$\pi$ & $\underline{h}$ & \\
\hline 0 & $\mathrm{t}$ & \\
\hline , & $\mathrm{y}$ & \\
\hline כ & $\mathrm{k}$ & \\
\hline 7 & $\mathrm{k}$ & end of word \\
\hline 3 & 1 & \\
\hline
\end{tabular}

\begin{tabular}{|c|c|c|}
\hline $\begin{array}{c}\text { square } \\
\text { script }\end{array}$ & transl. & \\
\hline מ & $\mathrm{m}$ & \\
\hline a & $\mathrm{m}$ & end of word \\
\hline J & $\mathrm{n}$ & \\
\hline 3 & $\mathrm{n}$ & end of word \\
\hline 0 & $\mathrm{~s}$ & \\
\hline ע & ، & \\
\hline פ & $\mathrm{p}$ & \\
\hline ๆ & $\mathrm{p}$ & end of word \\
\hline 3 & $\underline{S}$ & \\
\hline$Y$ & $\underline{s}$ & end of word \\
\hline$P$ & $\mathrm{q}$ & \\
\hline 7 & $\mathrm{r}$ & \\
\hline ש & ś & \\
\hline$\ddot{E}$ & $\check{s}$ & \\
\hline$\Omega$ & $\mathrm{t}$ & \\
\hline
\end{tabular}

\begin{tabular}{|c|c|c|c|}
\hline vowel & transl. & vowel & transl. \\
\hline & $\mathrm{i}$ & ?. & $\overline{1}$ \\
\hline & $\mathrm{e}$ & & \\
\hline & $æ$ & & \\
\hline - & $\mathrm{a}$ & & \\
\hline & 0 & & \\
\hline 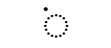 & o & $i$ & $\bar{o}$ \\
\hline & $\mathrm{u}$ & 7 & $\overline{\mathrm{u}}$ \\
\hline
\end{tabular}

\begin{tabular}{|c|c|}
\hline vowel & transl. \\
\hline \multirow{2}{*}{$:$} & $\partial$ \\
\cline { 2 - 2 } & \\
\hline$\because:$ & $\partial^{\mathrm{e}}$ \\
\hline$\because:$ & $\partial^{\mathrm{a}}$ \\
\hline$:$ & $\partial^{\mathrm{o}}$ \\
\hline
\end{tabular}




\section{Appendix B: Transcription of Yiddish names}

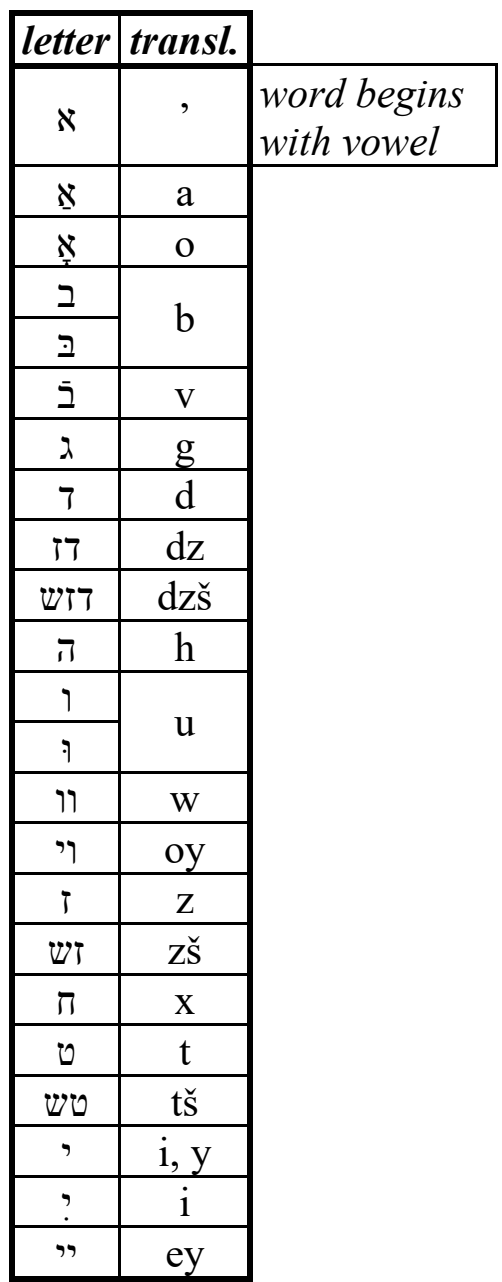

\begin{tabular}{|c|c|c|}
\hline letter & transl. & \\
\hline יֵ & ay & \\
\hline 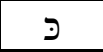 & $\mathrm{k}$ & \\
\hline כ & \multirow{2}{*}{$\mathrm{X}$} & \\
\hline 7 & & end of word \\
\hline ל & 1 & \\
\hline מ & \multirow{2}{*}{$\mathrm{m}$} & \\
\hline ם & & end of word \\
\hline 了 & \multirow{2}{*}{$\mathrm{n}$} & \\
\hline 3 & & end of word \\
\hline 0 & $\mathrm{~S}$ & \\
\hline ע & e & \\
\hline 9 & $\mathrm{p}$ & \\
\hline 5 & \multirow{3}{*}{$\mathrm{f}$} & \\
\hline פ & & \\
\hline ๆ & & end of word \\
\hline$y$ & \multirow{2}{*}{$\mathrm{c}$} & \\
\hline$r$ & & end of word \\
\hline$P$ & $\mathrm{k}$ & \\
\hline 7 & $\mathrm{r}$ & \\
\hline ש & $\check{\mathrm{s}}$ & \\
\hline ש & $\mathrm{s}$ & \\
\hline$ת$ & $\mathrm{t}$ & \\
\hline$\Omega$ & $\mathrm{S}$ & \\
\hline
\end{tabular}

As there was no fixed orthography of Yiddish when the data were recorded, the transliteration of Yiddish names sometimes deviates from the above table. 